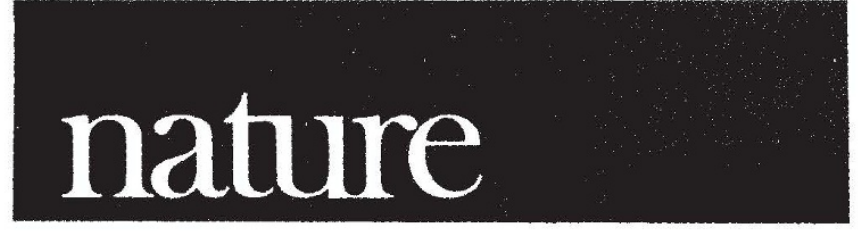

Volume 252

November 1, 1974

\section{Britain reviews its defence}

THE results of the British defence review initiated after the February election will soon be published and now, with Labour safely returned, they are likely to be received favourably by the government. Already political vultures are surrounding the Ministry of Defence and pointing to what they could achieve if handed a tiny fraction of the money allotted for defence; the impressive list runs from better hospitals to more performances of operas. The snag is that it is most unlikely that defence spending will be trimmed by any significant amount and certainly not by the $£ 1,000$ million, or $30 \%$, that the left wing has been demanding.

The early talk, and indeed that enshrined in Labour's recent election manifesto, was of bringing Britain's defence expenditure into line with that of its western European partners. Later in the election campaign, perhaps when the contents of the review had been made known to Labour politicians, the talk was more mutedly of not expanding expenditure and of carefully reconsidering overseas commitments when they come up for review. An uninformed guess, then, is that the review, far from revealing large areas of fat to be trimmed off, will simply say that Britain must be more modest in future. For the statistics on European comparisons show clearly that to talk of bringing expenditure into line with that of, say, France and Germany depends very much on what criterion one uses for being 'in line', and by one criterion, at least, Britain is irreproachably in step. The accompanying table provides some relevant figures on military spending in Western Europe.

Since 1950, military spending by European countries has grown relatively slowly, once inflation has been accounted for. Indeed in the years 1949-68 Britain's military expenditure grew on average by only $2.2 \%$ per year. France, with its nuclear development in the 1950s, showed a higher rate of $5 \%$ per year and West Germany, re-arming, grew by $6 \%$ per year. But all three countries had, by the late $1960 \mathrm{~s}$, stabilised their expenditure, and defence, in real terms, was hardly growing at all. As the table shows, growth subsequently re-established itself; only France has managed to keep things in check. Not too much, however, should be made of this recent growth, which may well reflect the difficulty of preventing military costs from rising more rapidly than other costs in inflationary times rather than any deliberately expansive policy.

What is evident from the table is the serious weakness that a depressed gross national product (GNP) imposes on a country with global and nuclear pretensions. In other ways Britain's expenditure looks quite lean and there is no conscription, by contrast with France and Germany, not only to put up the expense of the forces but to pull young men out of productive (and taxpaying) cccupations. It is the percentage-of-GNP indicator that makes Britain seem so far out of line; there are few other countries in the world which spend as much of their GNP on defence.

The question is thus not one of how to save a few million pounds here and there with small scale economies. It is much more fundamentally, should Britain go on spending defence money at the same per capita rate as her near neighbours, thereby providing highly sophisticated armaments for her forces, or should she recognise her economic limitations and aim to bring the figure of $4.9 \%$ down to nearer, say $3.5 \%$ ?

Presumably major surgery, such as the elimination of Britain's nuclear capacity, is the only way that such a saving could be achieved in the next ten years, and this is not an option that is likely to have been considered seriously. This is a shame; the rationale for possessing nuclear weapons is not so strong that it could not profit by occasional exposure and criticism if only to ensure that a new generation, to whom CND is only an historical evisode, is appraised of the disadvantages, as well as the supposed advantages of the possession of nuclear weapons. It would be unfortunate if these items of mass destruction came to be forgotten about by the public and thus subject to the pressures only of technological momentum and of those employed in their construction.

\begin{tabular}{|c|c|c|c|c|c|c|c|c|c|c|}
\hline \multicolumn{11}{|c|}{ Defence statistics for Britain, France and West Germany in 1973} \\
\hline & \multirow[b]{2}{*}{$\begin{array}{l}\text { Population } \\
\text { (million) }\end{array}$} & \multirow[b]{2}{*}{$\begin{array}{c}\text { GNP } \\
\text { (\$1000 } \\
\text { million) }\end{array}$} & \multirow[b]{2}{*}{$\begin{array}{l}\text { Inflation } \\
\text { 1969-73 }\end{array}$} & \multicolumn{4}{|c|}{ Military expenditure } & \multicolumn{2}{|c|}{ Armed forces } & \multirow[b]{2}{*}{$\begin{array}{c}\mathrm{R} \& \mathrm{D} \\
\text { as \% of } \\
\text { total } \\
\text { expendi- } \\
\text { ture }\end{array}$} \\
\hline & & & & $\$$ million & $\begin{array}{l}\text { Growth } \\
1969-73 \dagger\end{array}$ & $\%$ of GNP & Per capita & (thousands) & $\begin{array}{c}\% \text { of all } \\
\text { men aged } \\
18-45\end{array}$ & \\
\hline Britain & 56 & 177 & 7.7 & 8,673 & 10.9 & 4.9 & 155 & 352 & 3.4 & 9.0 \\
\hline France & 52 & 277 & 6.0 & 8,438 & 7.0 & 3.1 & 162 & 504 & 4.9 & 9.0 \\
\hline West Germany & 62 & 385 & 5.2 & 11,291 & 9.9 & 2.9 & 182 & 475 & 4.0 & 5.1 \\
\hline
\end{tabular}

+ Not corrected for inflation

Sources: The Military Balance 1974-1975 (International Institute for Strategic Studies.); SIPRI Yearbook 1973.

Be warned that all comparisons of military expenditure suffer from variations in definitions. Thus this table should be seen as no more than a general indication of comparisons. See page 102 of The Military Balance for more detail. 